\title{
The challenges of teaching English for Economics, with pluralist theories and fuzzy boundaries
}

\section{Nadeera Rajapakse}

\section{(2) OpenEdition}

1 Journals

\section{Electronic version}

URL: http://journals.openedition.org/asp/5869

DOI: 10.4000/asp.5869

ISSN: 2108-6354

\section{Publisher}

Groupe d'étude et de recherche en anglais de spécialité

\section{Printed version}

Date of publication: 2 March 2019

Number of pages: 111-115

ISSN: 1246-8185

\section{Electronic reference}

Nadeera Rajapakse, «The challenges of teaching English for Economics, with pluralist theories and fuzzy boundaries », ASp [Online], 75 | 2019, Online since 03 March 2019, connection on 01 November 2020. URL : http://journals.openedition.org/asp/5869 ; DOI : https://doi.org/10.4000/asp.5869

This text was automatically generated on 1 November 2020.

Tous droits réservés 


\title{
The challenges of teaching English for Economics, with pluralist theories and fuzzy boundaries
}

\author{
Nadeera Rajapakse
}

This report describes both the objectives and the contents of the English for economics course that Nadeera Rajapakse taught for twelve years at Université Paris 2 Panthéon Assas within the first year of the Master's degree. She mentions her questioning in relation to contents and the challenge she had to face in gathering her corpus of authentic documents in designing this course. Along with the social sciences, i.e. sociology or psychology, economic research is often based on quantitative studies. Qualitative research is also developed and the author draws our attention to the relevance of looking for alternative sources, focusing on a corpus of writings by heterodox economists with the objective of selecting texts representative of critical thinking today, in both macro- and micro-economics. The detailed syllabus of the course is depicted in the appendices.

The aim of her English for economics course is to help students reach the CEF C1 level in English, through various language activities. The skills she focuses on are those linked to the students' immediate needs as they are going to enter the job market at junior level position: $C V$ and job interviews, communication skills in a professional setting, oral interaction skills (notably Q\&A), and technical writing. In the section of the paper devoted to course design, she goes over some of the specific tasks she conceived to help students reach their learning objectives. Finally, her account of this teaching experience deals with the implementation of the course, and highlights the key issue of flipped teaching, group work and mixed communicative and cooperative techniques. (Séverine Wozniak)

\section{Introduction}

1 Assumptions can be dangerous, especially when made by an economist.

2 Jokes aside, that is the risk that I would like to focus on when it comes to teaching English for Economics. English for Specific Purposes (ESP) focuses on the objectives of 
language learning, set out by the domain or genre within which it is being learnt. When learning English for science subjects such as physics, chemistry or biology, the objectives are clear and the domain is often clearly demarcated. With English for Economics, the question underpinning this report is how fuzzy, porous boundaries of the discipline impact on the ESP teaching and methods. ${ }^{1}$

Much of economics' rigour comes from the dominant neoclassical theory, which holds at its core the "rationality" hypothesis. There are nonetheless, many alternative economic theories, heterodox theories, ${ }^{2}$ which question the narrow, simplifying assumptions. Amartya Sen (1977) questions the rationality hypothesis, stating that it is a form of reductionism and gross simplification. In Sen's words, the economic agent could be "rational" while being "rather a fool". ${ }^{3}$

4 As a result of these and other contentions, the varieties of thought have led to an opening up of the boundaries of the discipline. Economics has, for instance, borrowed from psychology (behavioural economics), from neuroscience (neuro-economics).

Reviewing the rationality hypothesis and the accompanying embrace of other social science approaches has made the boundaries of economics fuzzier. It is not my intention to discuss whether that is desirable or not. Instead my question is about how this trend impacts on teaching ESP - English for Economics.

Myers (1992) has discussed the paradox that makes economics textbooks better at transmitting a canon of knowledge, and therefore, worse at fostering critical reading. According to Swales,

there are presumably a number of ways of trying to resolve Myers's paradox. One is to produce an alternative anti-genre type of textbooks that conveys a sense of the subject as 'discourse and conversation' as Klamer and McCloskey are apparently trying to do for Economics. (1993: 224)

ESP also runs the risk of providing a "canon of knowledge" if it follows mainstream (textbook) economic theory.

8 With these questions in mind, I set out to make the ESP experience one that would avoid teaching a "canon of knowledge", and would instead enhance students' awareness of the plurality of economic thought, all the while improving students' language skills. It is an approach that emphasises "critical thinking" and it encompasses the purely communicative and terminological objectives that are set out.

In the following report, I outline the course that I taught for several years, giving details of its curricula and content, along with a description of how the class work was organised, teaching and evaluation methods, and finally, students' feedback. While the content was common to all classes in first-year Masters level at the university, all the information provided here is based solely on my classes and reflects the methods and pedagogical approach that I adopted. ${ }^{5}$

\section{Context}

\section{The course}

M1 English for Economics is a compulsory course component for first-year Masters' students at the University Paris 2, Pantheon-Assas, running over two semesters, consisting of one and a half hours of class every week. M1 English for Economics classes 
usually have 22 students per group. I taught this course for over twelve years, during which I coordinated the programme for three years. As coordinator, I was involved in elaborating the syllabus and content, which was revised and updated by the team of teachers every year.

\section{Objectives}

11 The aim of the ESP classroom is to instruct learners to successfully develop a broad range of skills. The objectives of the above-mentioned course have been discussed and defined over several years, taking into consideration the needs of the students. They can be divided into three categories. First, the aim of avoiding "canons" of knowledge, and using ESP to make students gain deeper understanding of the specialised knowledge, while fostering critical thinking. Second, the stated objectives of each semester. Third, we work on the language activities as they are defined by the Common European Framework of Reference (2018). At M1 level students are expected to reach a C1 standard in these skills. These three levels are not hierarchically differentiated, where one is given priority over the others. Instead, they are compatible and interwoven.

12 The objectives of the course are set out each semester. In the first semester, the content is arranged with the objective of understanding key macroeconomic concepts, while the second semester focuses on the corporate world. Thus, the first semester objectives stated in the students' hand-out are as follows:

13 Professional communication skills: We will work towards enhancing your communication skills with a view to producing and delivering effective presentations in a professional setting. The aim is to be able to speak clearly and knowledgeably on a specific topic. You must also aim at stimulating discussion among the group.

Question and answer skills: It is important to be able to ask questions for clarification or for more information. Reformulating and asking questions are also part of the communication skills we will be working on.

15 Writing skills: Being able to write a good commentary by interpreting economic data is very important in a professional setting. This involves not just describing variations, but also analysing trends. We will work on grammar structures and vocabulary that will help you improve your writing style, while also focusing on content analysis.

Understanding key macroeconomic concepts: The course addresses several macroeconomic issues such as economic indicators and data, regulation and public policies, Brexit and international affairs, and models of capitalism. We intend to deepen your understanding of these issues. (M1 English for Economics, Students hand-out). 


\section{First semester objectives}

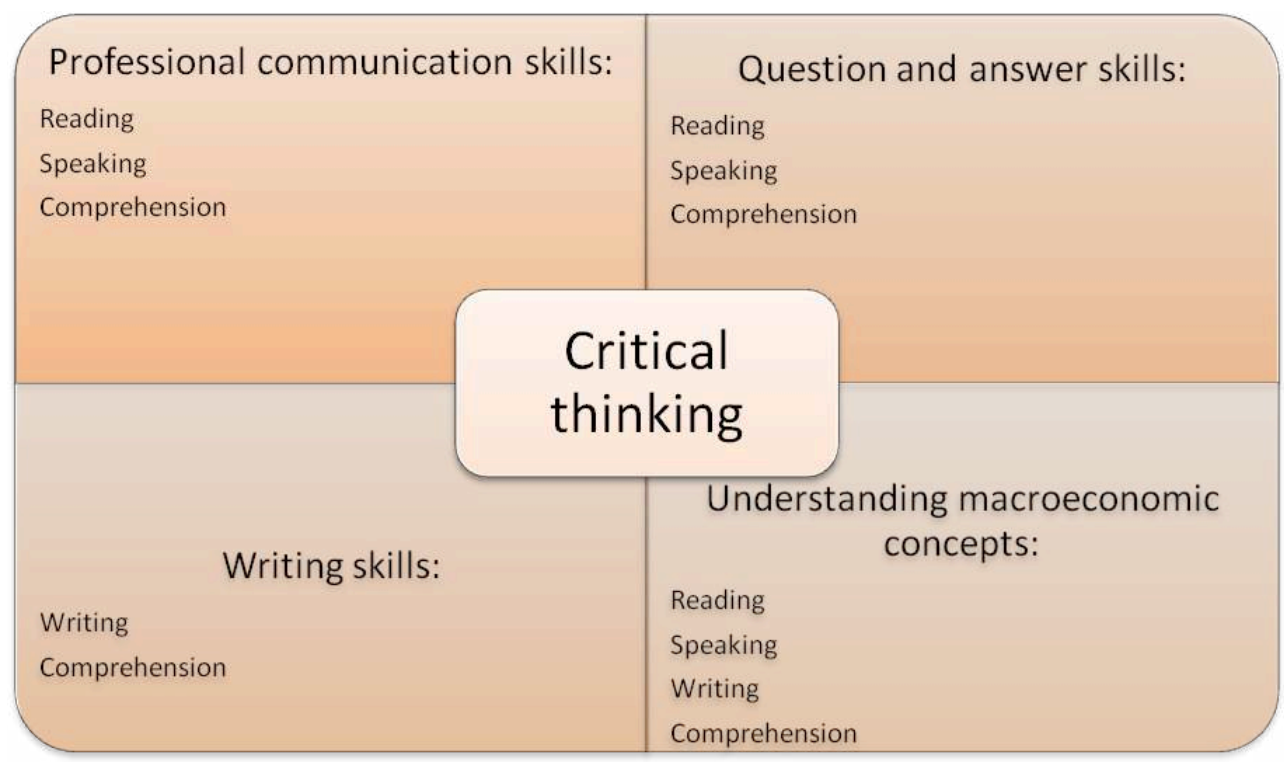

The objectives of the second semester are:

$\mathrm{CV}$ and Cover letter writing.

Professional communication skills: Role plays and specialised discussions with technical terms and vocabulary.

Understanding key concepts relating to the corporate world and business structures (M1 English for Economics, Students hand-out).

\section{Second semester objectives}

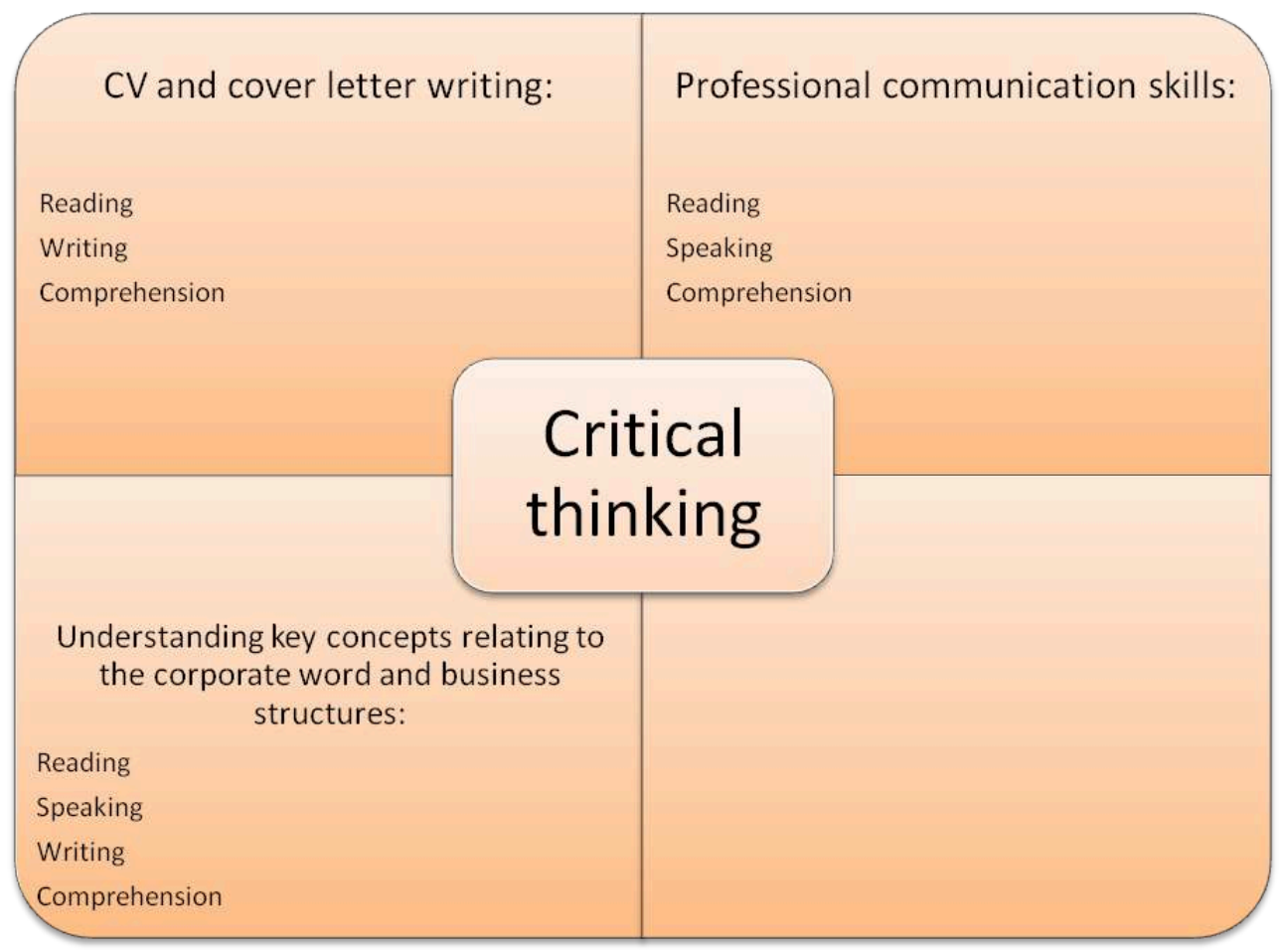


21 M1 level students are the most suited for this approach. They have a solid grounding in economics and have chosen a specialised area for their Masters studies. In addition to the general economic theories (micro economics, macro economics, international trade, political economy, statistics, etc.), they also have knowledge of their chosen field (financial economics, game theory, decision-making, times series, contemporary geopolitics, management). Furthermore, they have often come across some heterodox economic theories (behavioural economics, institutional economics, etc.) inside and outside university, which makes them more receptive to the idea of pluralist thought in economics. For this cohort then, the objectives above are defined in order to make their ESP experience develop a greater sense of debate and discussion.

\section{Course design}

\section{Content-based Instruction}

22 ESP, as opposed to general language acquisition, falls within the scope of content-based language skills. Determining content, therefore, requires prior clarification of its boundaries and limits. In this respect, the content chosen for class work aims at fulfilling both the list of stated objectives as well as the broader idea of fostering pluralist thought. The material used is authentic in keeping with the practice in ESP classes. ${ }^{6}$

Each chapter of the students' hand-out ${ }^{7}$ contains reading material, listening comprehension links, comprehension and discussion questions, grammar reviews and vocabulary highlights. While these categories of material are similar to what is found in most language learning methods and books, it is the content that allows the teachers to direct discussion towards "heterodox" thinking (see Appendix 1).

\section{Pedagogy and teaching methods}

Making the class as interactive as possible and ensuring that students are always engaged is one of my priorities and challenges. I use a mix of communicative and cooperative learning techniques. ${ }^{8}$

During the one and a half hours of class, students are called upon to use all the language activities, with special emphasis on speaking. Prior to class, they are given reading assignments, with comprehension and discussion questions, as well as further reading references and research tips. Thus, they are expected to be prepared and able to discuss the texts or material each week. In addition to the prepared answers, I invite students to comment on the subject, give their opinion, and talk about their own experiences, in order to make it as lively as possible.

Part of the class work is done in small groups of about three - four students: they are given case studies, role play material, debate topics, and other group work, which they prepare for a few minutes. These activities are chosen so as to enable students to apply theoretical knowledge to practical examples derived from professional environments.

Then each group is invited to participate. I insist that each member of the group speaks, regardless of their level in English. The entire class then debriefs on the final 
results or outcomes of the group work. This is then summarised in a written report by the students, either working in groups or individually.

Students also prepare class presentations, on topics of their choosing, keeping in line with the main themes of the semester. I emphasise the importance of having one or two key arguments around which the content and ideas need to be arranged - the presentation assessment sheet is given in Appendix 2.

Student presentations are followed by a question-and-answer session, where the audience is invited to react, comment, ask questions. (At the beginning of the semester, I inform students that participation in the question-and-answer session is one of the main components of the participation grade of the semester.) This general discussion is usually quite animated and the entire class is involved. It is also important to draw the speakers out, because it forces them to answer spontaneously, without a script, which most manage to do very well.

In keeping with the "critical thinking" objective, one of the criteria of a good presentation is when speakers show awareness, or even understanding, of various lines of thinking on the subject. Indeed, when the presentation evaluation criteria are explained to them beforehand (appendix 2), most of them make a commendable effort to ensure that their topic is well-rounded. In addition, the question and answer session also reveals a diverse range of references and examples, which reflect the fact that students can and do draw from a variety of theories and thought, especially when encouraged to do so.

31 Table 1 provides examples of some of the activities done in class. The corresponding linguistic objectives along with some examples of non-linguistic objectives are given.

Table 1: Examples of tasks done in class

\begin{tabular}{|c|c|c|c|}
\hline Examples of material & Examples of activities & Linguistic objectives & $\begin{array}{l}\text { Examples of non- } \\
\text { linguistic objectives }\end{array}$ \\
\hline \multicolumn{4}{|l|}{ Semester 1} \\
\hline \multirow{3}{*}{$\begin{array}{l}\text { Chapter } 1 \text { - Measuring } \\
\text { Economic } \\
\text { Performance }\end{array}$} & $\begin{array}{l}\text { Listening } \\
\text { comprehension } \\
\text { Discussion on the } \\
\text { importance of choosing } \\
\text { what we measure }\end{array}$ & $\begin{array}{l}\text { Specialised vocabulary } \\
\text { (indicators and } \\
\text { methods) }\end{array}$ & $\begin{array}{l}\text { Critical thinking on the } \\
\text { limits of indicators }\end{array}$ \\
\hline & Commentaries on graphs & Writing skills & Analytical skills \\
\hline & $\begin{array}{l}\text { Discussing alternate } \\
\text { theories }\end{array}$ & $\begin{array}{l}\text { Spoken interaction } \\
\text { Comprehension }\end{array}$ & $\begin{array}{l}\text { Opening up to } \\
\text { heterodox theories }\end{array}$ \\
\hline \multirow{2}{*}{$\begin{array}{l}\text { Chapter } 2 \text { - Financial } \\
\text { and Environmental } \\
\text { Regulation }\end{array}$} & $\begin{array}{l}\text { Reading on recent } \\
\text { financial regulation } \\
\text { (USA, Europe) }\end{array}$ & \multirow{2}{*}{$\begin{array}{l}\text { Reading and listening } \\
\text { comprehension } \\
\text { Spoken interaction }\end{array}$} & $\begin{array}{l}\text { Debating on market } \\
\text { mechanisms, rational } \\
\text { behaviour }\end{array}$ \\
\hline & $\begin{array}{l}\text { Discussing behavioural } \\
\text { economics }\end{array}$ & & $\begin{array}{l}\text { Understanding } \\
\text { behavioural economics }\end{array}$ \\
\hline
\end{tabular}




\begin{tabular}{|c|c|c|c|}
\hline $\begin{array}{l}\text { Chapter } \quad 3 \\
\text { International Affairs }\end{array}$ & $\begin{array}{l}\text { Debating on Brexit } \\
\text { Debating on } \\
\text { international capital and } \\
\text { labour flows }\end{array}$ & $\begin{array}{l}\text { Spoken production } \\
\text { and interaction } \\
\text { Comprehension }\end{array}$ & $\begin{array}{l}\text { Researching and } \\
\text { referencing heterodox } \\
\text { thought }\end{array}$ \\
\hline $\begin{array}{l}\text { Chapter } 4 \text { - Models of } \\
\text { Capitalism }\end{array}$ & $\begin{array}{l}\text { Analysing presidential } \\
\text { speeches on economic } \\
\text { affairs }\end{array}$ & $\begin{array}{l}\text { Reading and listening } \\
\text { comprehension } \\
\text { Spoken interaction }\end{array}$ & $\begin{array}{l}\text { Analytical skills } \\
\text { Discussing economic } \\
\text { theory and policy }\end{array}$ \\
\hline \multicolumn{4}{|l|}{ Semester 2} \\
\hline $\begin{array}{l}\text { Chapter } 1 \text { - Company } \\
\text { Structures }\end{array}$ & $\begin{array}{l}\text { Describing } \\
\text { organizational charts } \\
\text { Describing jobs }\end{array}$ & $\begin{array}{l}\text { Specialised vocabulary } \\
\text { (indicators and } \\
\text { methods) }\end{array}$ & $\begin{array}{l}\text { Understanding job } \\
\text { requirements } \\
\text { Thinking about career } \\
\text { plans }\end{array}$ \\
\hline $\begin{array}{l}\text { Chapter } 2 \text { - Human } \\
\text { Resource }\end{array}$ & $\begin{array}{l}\text { CV writing } \\
\text { Role plays - job } \\
\text { interviews } \\
\text { Role play - Managing HR }\end{array}$ & $\begin{array}{l}\text { Spoken production } \\
\text { and interaction } \\
\text { Comprehension } \\
\text { Writing }\end{array}$ & $\begin{array}{l}\text { Talking about oneself } \\
\text { Establishing career } \\
\text { plans } \\
\text { Working on soft skills }\end{array}$ \\
\hline Chapter 3 - Marketing & $\begin{array}{l}\text { Case studies on the } \\
\text { marketing mix } \\
\text { Role plays } \\
\text { Crowdfunding } \\
\text { crowdsourcing }\end{array}$ & $\begin{array}{l}\text { Spoken production } \\
\text { and interaction } \\
\text { Comprehension }\end{array}$ & $\begin{array}{l}\text { Practising sales pitch } \\
\text { Negotiating skills }\end{array}$ \\
\hline $\begin{array}{l}\text { Chapter } 4-\text { The } \\
\text { Banking Industry }\end{array}$ & $\begin{array}{l}\text { Role plays - Banking } \\
\text { jobs } \\
\text { Role plays - Client } \\
\text { service }\end{array}$ & $\begin{array}{l}\text { Spoken production } \\
\text { and interaction } \\
\text { Comprehension }\end{array}$ & $\begin{array}{l}\text { Problem-solving skills } \\
\text { Working on empathy } \\
\text { and listening }\end{array}$ \\
\hline $\begin{array}{l}\text { Chapter } 5 \text { - Working } \\
\text { across Cultures }\end{array}$ & $\begin{array}{l}\text { Role plays - Cross- } \\
\text { cultural communication } \\
\text { Debates - Cultural } \\
\text { stereotypes / Cultural } \\
\text { appropriation }\end{array}$ & $\begin{array}{l}\text { Spoken production } \\
\text { and interaction } \\
\text { Comprehension }\end{array}$ & $\begin{array}{l}\text { Working on empathy } \\
\text { and listening } \\
\text { Communicative skills }\end{array}$ \\
\hline
\end{tabular}

\section{Assessment of learning outcomes}

32 I will discuss results in two ways: first, through my evaluations of students' results, in terms of reaching objectives, and second, by looking at other categories of criteria from the feedback and evaluation given by the students of the course. In the first case, the results will give a direct indication of the success of the course, while the second series of results could be interpreted as an impact on the holistic learning experience of students. 


\section{Assessments}

Students are assessed on the stated language activities throughout the semester. They have a midterm written test, an oral presentation to do before class, and an end-ofsemester oral examination. For each assessment, their marks are equally divided (50-50) between content and language. The four objectives are assessed through these evaluation methods.

Fulfilling course objectives

\section{Semester 1}

Professional communication skills: students fulfil this objective well. Class presentations are often of very good quality, showing commendable research skills and sound preparation. Marks range from 20 to 45 out of 50 (Appendix 2). Above all, students manage to satisfy most of the evaluation criteria.

Question and answer skills: Here too, students obtain good results. This activity is evaluated during the discussion following presentations, but also during class discussions. While grammar structures leave room for improvement, their ability to ask a question clearly and invite a satisfying answer improves considerably over the two semesters.

Writing skills: Here students have lower marks than for their speaking and communication skills. Very often, the low marks reflect weak grammar and language structures, whereas the second component, i.e. content, is often satisfactory, if not, good.

Understanding macroeconomic concepts: This objective is evaluated directly, through vocabulary questions and through how they are put into practice in speaking and writing. Students generally learn - master and put into practice - a fairly long list of specialised words and concepts throughout the semester. At the same time, the class discussions and, to a lesser extent, the written work, reveal that students have also acquired a broader list belonging to heterodox economic thought.

\section{Semester 2}

CV and cover letter-writing skills: The midterm written test, in addition to written assignments throughout the semester allows me to assess their progress in this domain. Students are often very keen on this activity, which is of concrete and almost immediate import to them. They show good mastery of vocabulary, as well as of the necessary grammar structures.

Professional communication skills: Students are graded on their role plays, as well as on other group discussion activities during the semester. By using a variety of role plays, of different types, students manage to relate to and identify with different personalities, which makes this a successful way of improving their communication skills. As mentioned earlier, it pushes them to improve their vocabulary, but also their broader communication skills (empathy, understanding, tact, along with negotiating skills, cross-cultural awareness, etc.).

Understanding key concepts of the corporate world and business structures: Both the written and spoken production and interaction in class are used to evaluate this skill. While this is a straightforward evaluation of their vocabulary and understanding, it is also an indication of their positions with regard to the "critical thinking" objective. 

can fill out anonymously, giving their feedback on the course (Appendix 3). In general, students are satisfied with the way the course is designed to achieve the objectives set out at the beginning of the semester. In terms of language competencies, there is an overall sense of achievement in speaking skills, while writing skills are met only for a smaller proportion of students. Students also appear to appreciate the interactive, collaborative and communicative techniques used in class, which, for many, is a source of motivation, while also being a way of boosting self-confidence. Finally, many students mention that the course enabled them to grasp deeper understanding of the core discipline, while a few confirm that they enjoyed discussing new ideas. summed up as follows: There is evidence (as seen in the indirect references to new ideas in student evaluations) that the approach produces results. Students are more receptive to heterodox theories; they actively seek out alternative arguments to mainstream economic ideas (as seen in their class presentations); they participate more confidently and willingly in debates and discussions.

While this approach requires further qualitative and quantitative research (via surveys, questionnaires and analysis of gathered information), I am convinced that it benefits students greatly in terms of developing soft skills. Greater cultural awareness, empathy, team work, flexibility and creativity seem to go hand-in-hand with this approach. Students also gain in confidence as a result of being in an environment that promotes critical thinking and pluralist thought. 


\section{Conclusion}

Introducing pluralist economic theories as part of the content of English for Economics classes strengthens, rather than contradicts, the idea that ESP is an approach which needs to be conceived based on the needs and methods of the discipline at hand. However, for economics, it entails that the approach becomes less specific, as the boundaries of the discipline become more porous. By teaching students that agents are rational, we are in a way, shaping them to believe it and to adopt such behaviour themselves. English for Economics classes then provide an opportunity to present economics as multidisciplinary, with fuzzy boundaries, and thus, we are less likely to end up with "rational fools."

\section{BIBLIOGRAPHY}

BASTURKMEN, Helen. 2010. Developing Courses in English for Specific Purposes. Basingstoke: Palgrave Macmillan.

Council of Europe. 2018. Common European Framework of Reference: Learning, Teaching and Assessment. Strasbourg: Council of Europe.

DUDLEY-EVANS, Tony \& Maggie ST JOHN. 1998. Developments in English for specific purposes: A multidisciplinary approach. Cambridge: Cambridge University Press.

HUTCHINSON, Tom \& Alan WATERS. 1987. English for Specific Purposes: a learner-centred approach. Cambridge: Cambridge University Press.

MCCLOSKEY, Donald M. 1983. “The rhetoric of economics". Journal of Economic Literature 21, 481-517. MYERS, Greg. 1992. "Textbooks and the sociology of scientific knowledge”. English for Specific Purposes 11, 3-17.

SEN, Amartya. 1977. "Rational Fools: A critique of the behavioral foundations of economic theory". Philosophy and Public Affairs Summer, 314-377.

SWALES, John. 1990. Genre Analysis. Cambridge: Cambridge University Press.

SWALES, John. 1993. “The paradox of value: six treatments in search of the reader”. In HENDERSON, W, T. DUDLEY-EVANS \& R. BACKHOUSE (eds.), Economics and language. London: Routledge, 223-238.

\section{APPENDIXES}

\section{Appendix 2 - Evaluation of student presentations}

\begin{tabular}{|l|l|}
\hline Presentation Skills & Marks out of 5 \\
\hline
\end{tabular}


1. Clearly communicates the subject matter.

Speaks in a way that interests the audience.

Explains the subject simply so that everyone understands.

2. Speaks confidently and articulately in good English

Grammar and syntax

Confidence

Uses technical / specialized vocabulary

Good diction

Speech is lively and interactive

3. Uses appropriate body language

Exhibits good body posture

No distracting hand movements

Maintains good eye contact with audience

4. Validates students' questions and comments

Stimulates discussion

Responsive to questions, able to answer.

5. Uses visuals appropriately

Effective visual materials

Content/Organization

1. Originality, creativity in choice of subject

Extent, quality and appropriateness of research

2. Knowledge and understanding of the material presented

Familiar with subject matter

Exhibits knowledge of subject

Answers questions with confidence

3. Well-organized and flows logically

States objectives/goals clearly

Presents results clearly

Delivers the main message effectively

4. Clear and logical examples and good references 


\begin{tabular}{|l|l|}
\hline 5. Quality of argument & \\
Original point of view / argument & \\
Takes risks & \\
Presents opinions & \\
Thought provoking & \\
\hline Overall Impression & Total out of 50 \\
\hline
\end{tabular}

\section{Appendix 3 - Evaluation form for students to give their feedback on the course}

1. Le cours a-t-il correspondu aux objectifs annoncés (descriptif, premier cours)?

Si oui, comment; si non, pourquoi?

2. Que pensez-vous de la répartition entre les quatre compétences et/ou de la façon dont elles ont été abordées en cours ? Développez vos réponses.

Compréhension écrite

Compréhension orale

Expression écrite

Expression orale

3. Quels sont selon vous vos besoins linguistiques? Le cours vous a-t-il permis de progresser dans ces domaines, ou bien d'autres domaines?

4. Que pensez-vous des aspects suivants du cours? Développez vos réponses.

Interactivité

Activités proposées

Thèmes proposés

Exposés

5. Comment décririez-vous le cours ou le module en quelques mots?

6. Quels ont été les aspects les plus positifs du cours? Les plus négatifs?

7. Avez-vous des suggestions pour améliorer le cours?

\section{NOTES}

1. Hutchinson and Waters (1987) viewed ESP as an "approach", not a "product", meaning that it "does not involve a particular kind of language, teaching material, or methodology" (1987: 2). For Dudley-Evans and St John, ESP is a discipline that attempts to meet the needs of a specific population of students, employs methodologies and materials from the discipline it is centred on, and focuses on the language and discourse related to it (1998).

2. According to <http://diversifyingecon.org> "[t]he term "heterodox" refers to any idea that critiques or stands in contrast to conventional, generally-accepted canon - that is, the status quo. As such, heterodox views are always unorthodox, frequently interdisciplinary, and, more often than not, dissident. Heterodox theories of economics can depart from mainstream or neoclassical 
economics in a multitude of ways. Most take issue with narrow focus of economics today, which is primarily concerned with the rational agent and the distribution of material wealth."

3. The rationality hypothesis is based on two ideas, consistency of choice, and utility maximization. Sen explains the first: "A person is given one set of preference ordering, and [...] when the need arises this is supposed to reflect his interests, represent his welfare, summarize his idea of what should be done, and describe his actual choices and behaviour" (1977: 335). For Sen, this is an extreme type of reductionism. In his words, if the person "has no use for these distinctions, he may be 'rational' in the sense of revealing no inconsistencies, but he must be a bit of a fool" (1977: 336).

4. Swales has advocated the importance of a balanced argumentation by way of evaluating alternative viewpoints and anticipating possible objections (1990).

5. I am an ESP teacher as well as a researcher in economics and I relied a great deal on my knowledge of economics to design and teach this course. This was not necessarily the case for the other teachers of this course, and we were each able to adapt the material according to our interests and use different teaching methods, while working towards the same objectives.

6. "Authentic texts play an important role in demonstrating 'real language use" (Basturkmen 2010: 63).

7. The students'hand-out is designed by the team of M1 teachers using material derived from economics textbooks, articles from the press, research papers and is printed and distributed for use by the M1 students at the university.

8. These techniques enable English language acquisition, notably the four language skills, through a combination of collaborative work in the target language (group work in research, reading, writing and discussing) and communicative tasks.

\section{INDEX}

Mots-clés: anglais pour l'économie, descriptif de cours

Keywords: course syllabus, English for Economics

\section{AUTHOR}

\section{NADEERA RAJAPAKSE}

Université Paris 1 Panthéon-Sorbonne, nrajapakse@hotmail.com 